\title{
How long does it take for putting on sneakers? An obsessive-compulsive ritual
}

\section{Quanto tempo leva para se colocar um tênis? Um ritual obsessivo-compulsivo}

Péricles Maranhão-Filho, Marcos Martins da Silva, Marco Antonio Lima

A 24-year-old man with an 11-year history of obsessivecompulsive disorder with good insight ${ }^{1}$ presented with an otherwise unremarkable neurologic examination. Besides tic-like compulsions and obsessional thoughts about harming himself, he takes 1 minute and 25 seconds to put on each foot sneaker, a task usually expected to be accomplished in less than 5 seconds. The ritual (Figure) includes fingers repetitive movements (A to F), the need to hear the pounding of feet on the ground $(\mathrm{G}, \mathrm{H})$, and marching in the same place for sixteen
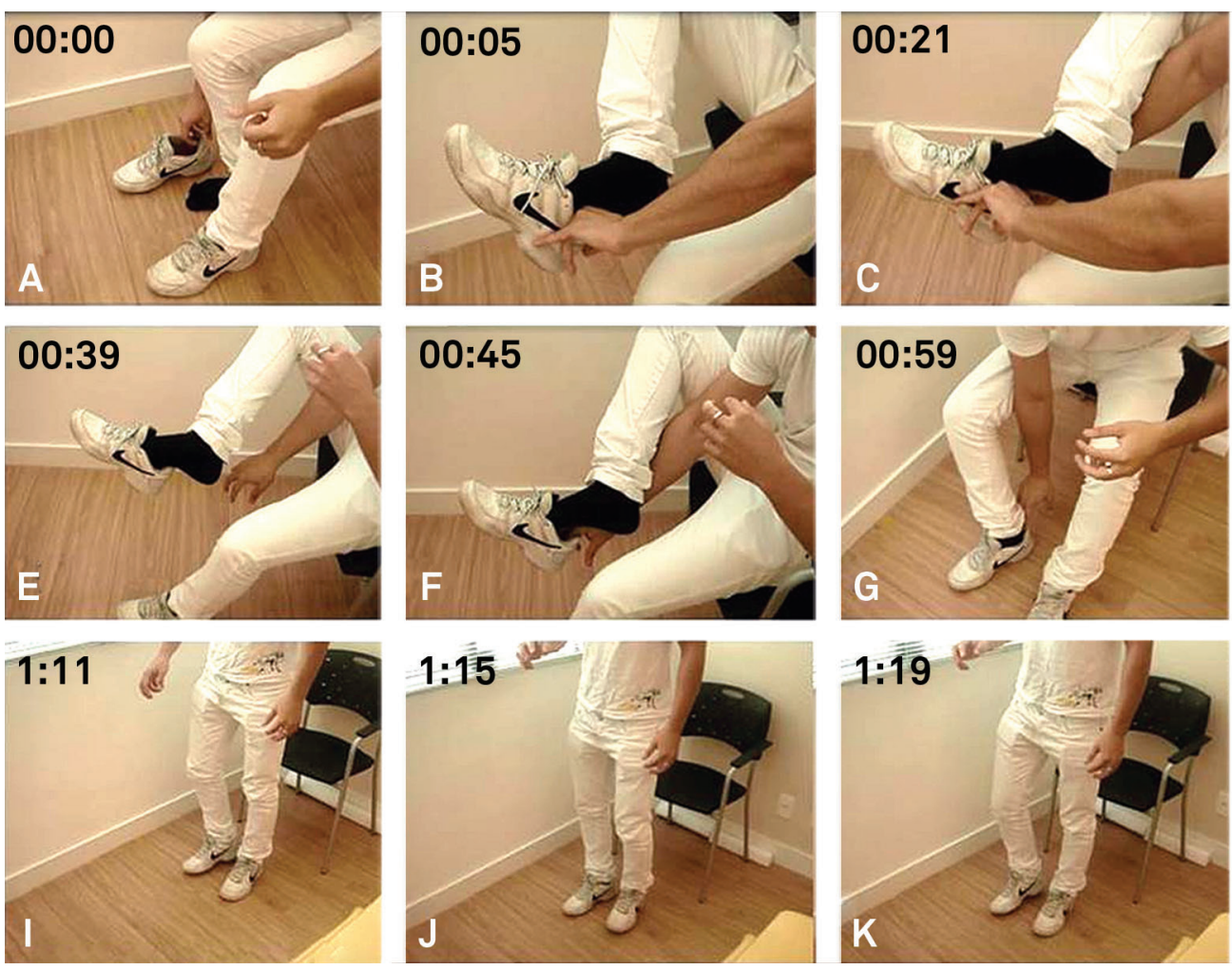
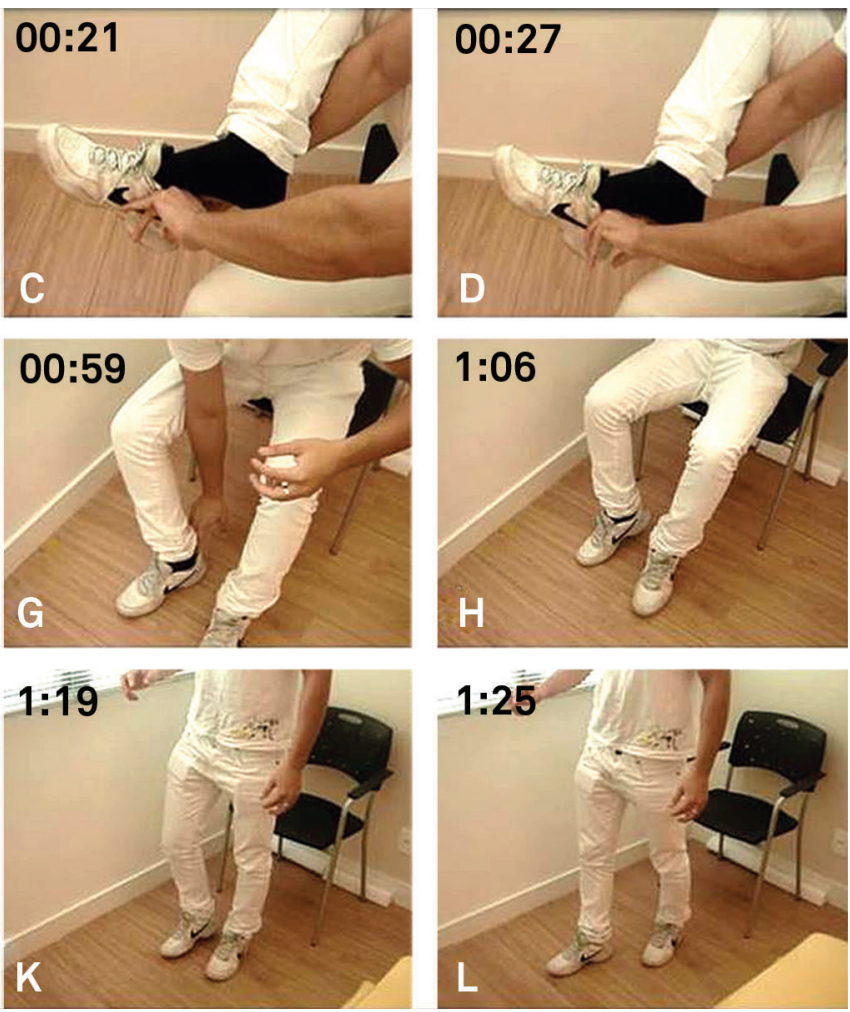

steps (I to L). Obsessive-compulsive disorder is a distressing, time-consuming disease to which the neuropsychiatric science owes an adequate etiopathogenesis and treatment ${ }^{2}$.

\section{Acknowledgments}

The authors are in debit with Péricles Maranhão Neto for his technical assistance.
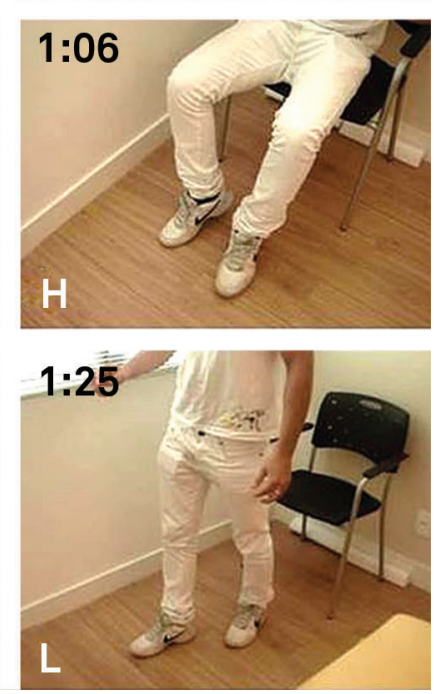

Figure. Ritualistic behavior with repetitive movements sequence to put on the right sneaker. Images extracted from a movie with the time in minutes appointed in the top.

\section{References}

American Psychiatric Association (APA). Diagnostic and Statistical Manual of Mental Disorders, 5th Edition (DSM-V). Washington, DC, American Associated Press 2013.
2. Leckman JF, Rauch SL, Mataix-Cols D. Symptom dimensions in obsessive-compulsive disorder: implications for the DSM-V. CNS Spectr 2007:12:376-387.

Departamento de Neurologia, Hospital Universitário Clementino Fraga Filho, Universidade Federal do Rio de Janeiro, Rio de Janeiro RJ, Brazil.

Correspondence: Péricles Maranhão Filho; Av. Prefeito Dulcídio Cardoso, 1680/1802; 22620-311 Rio de Janeiro RJ, Brasil; E-mail: pmaranhaofilho@gmail.com/ www.neurobarra.com

Conflict of interest: There is no conflict of interest to declare.

Received 17 March 2014; Received in final form 20 March 2014; Accepted 09 April 2014. 